\title{
STUDY ON THE STABILITY OF TRIVALENT CATIONS GADOLINIUM (Gd) DOPED FERRIC OXIDE $\left(\mathrm{Fe}_{2} \mathrm{O}_{3}\right)$ THROUGH ATOMISTIC MODELING
}

\author{
Anggi Suprabawati ${ }^{1, a^{*}}$, Iman Rahayu ${ }^{1, b}$, Atiek R. Noviyanti ${ }^{1, c}$, Anni Anggraeni ${ }^{1, d}$, Heri Jodi ${ }^{2, a}$ \\ ${ }^{1}$ Department of Chemistry, Faculty of Mathematics and Natural Sciences, Universitas \\ Padjadjaran, Bandung, West Java, Indonesia \\ ${ }^{2}$ Pusat Sains dan Teknologi Bahan Maju (PSTBM) Badan Tenaga Nuklir Nasional Puspiptek \\ Serpong Setu Tangerang Selatan 15314 Banten Indonesia \\ a* suprabawati.anggi@gmail.com (corresponding author), biman.rahayu@unpad.ac.id, \\ catiek.noviyanti@unpad.ac.id, dAnggraeni173@gmail.com, eherieldi@gmail.com
}

\begin{abstract}
Abstrak
This research is aimed to study the stability of the structure $\mathrm{Fe}_{2} \mathrm{O}_{3}$ doped with trivalent cations Gadolinium $(G d)$ into compound $\mathrm{Fe}_{1-x} \mathrm{Gd}_{x} \mathrm{O}_{2-} \delta$ through atomistic modeling and Bond Valence Sum (BVS) calculations. Short range potential used in this study was Buckingham potential. Result of geometry optimization at constant pressure shown the more of the concentration and the size of substituting dopant offerric oxide $\left(\mathrm{Fe}_{2} \mathrm{O}_{3}\right)$ increase, the more positive the lattice energy of the doped structure is, so that the stability of the doped $\mathrm{Fe}_{2} \mathrm{O}_{3}$ structure decreases.
\end{abstract}

Kata kunci: stability, structure, $\mathrm{Fe}_{1-x} G d_{x} \mathrm{O}_{2}-\delta$, atomistic, modeling Bond Valence Sum (BVS) calculations

\section{Introduction}

For some times, information and comprehension of the chemical structure of $\mathrm{Fe}_{2} \mathrm{O}_{3}$ were applied as soft magnetic application such as transformator core, inductor, and memory device in high frequency application like microwave system. At several spinel structures shown super conductivity at low temperatures (Nindha, 2017). As previous study about the stability of trivalent cations doped Zirconia (Kilo, 2019) has produced extensively benefit through the development of computation modeling technique. The stable structures which may be obtained from the doped ferric oxide by trivalent cations gadolinium (Gd) could be learned at the first place through atomistic modeling before the material is synthesized at laboratory. $\mathrm{Fe}_{2} \mathrm{O}_{3}$ is a precursor material which is a kind of semiconductor in the use of lithium battery (Li) (Peters, 2017) 
$\mathrm{Fe}_{2} \mathrm{O}_{3}$ is a polymorph oxide which has three phases : alpha rhombohedral $\alpha$ rhombohedral (Yichuan, 2013) form decomposes within $105^{\circ} \mathrm{C}$, cubic bixbyte decomposes within $150^{\circ} \mathrm{C}$, cubic spinel decomposes within $50^{\circ} \mathrm{C}$ and orthorhombic decomposes within $92^{\circ} \mathrm{C}$ (Milan, 2014). Cubic spinel phase is stated unstable at low temperatures. The unstable of Orthorombic $\mathrm{Fe}_{2} \mathrm{O}_{3}$ phase at $92^{\circ} \mathrm{C}$ needs to be stabilized by partially adding cations with same valence $\left(\mathrm{X}^{+3}\right)$ to get a good electronic mobility. Ramanarayanan (1994) states that electronic mobility $\left(\sigma_{\mathrm{e}}\right)$ is not influenced by the selection of dopant as long as the valence material same as the intended material. In $\mathrm{Fe}_{2} \mathrm{O}_{3} \mathrm{Fe}^{+3}$ doped by Gadolinium $\left(\mathrm{Gd}_{2} \mathrm{O}_{3}\right) \mathrm{Gd}^{3+}$ which has the same valence. Without dopant, structural instability occurred and phase separation happened at high temperatures $\left(>50^{\circ} \mathrm{C}\right)$.

The stability of trivalent cations $\left(\mathrm{M}^{3+}\right)$ $\mathrm{Gd}^{3+}$ in $\mathrm{Fe}_{1-\mathrm{x}} \mathrm{Gd}_{\mathrm{x}}$ depends on suitability factors of the radius between $\mathrm{Fe}^{3+}(0,60 \AA)$ and cations $\mathrm{Gd}^{3+}$ which has $0,938 \AA$ radius and also the concentration from those ions (Oxtoby, 2003). As a result of it, the formed stable structure is determined by those factors. The oxide structure of soil is rarely determined by cations radius. Cation $\mathrm{Gd}^{3+}$ has two structural forms including cubic structure (Pearson symbol cI80, Ia3, No. 206) and monoclinic (Pearson symbol mS30, space group C2 / m, DOI: http://dx.doi.org/10.12962/j25493736.v5i2.7780
No. 12). At room temperature, cubic structure is more stable. The change of phase into monoclinic structure takes place on $1200^{\circ} \mathrm{C}$. Temperatures above $2100^{\circ} \mathrm{C}$ until melting point on $2420^{\circ} \mathrm{C}$ is dominated by hexagonal phase (Wells, 1994). In this research, trivalent cations from Gadolinium $\mathrm{X}^{3+}\left(\mathrm{Gd}^{3+}=0,938\right.$ $\AA$ A) which substituting partially $\mathrm{Fe}^{3+}$ from orthorhombic phase is analyzed based on the increase of $\mathrm{M}^{3+}$ cation concentration. The Gadolinium (Gd) in one of lanthanide that have a $4 \mathrm{f}^{7} \quad 5 \mathrm{~d}^{1} \quad 6 \mathrm{~s}^{2}$ combination of configuration. The used cations of $\mathrm{Gd}^{3+}$ among other trivalent cations is because have a middle radius of $\mathrm{Ln}^{3+}(\mathrm{pm})$ and have a 16 free position of electron instead of Lantanum (La) that have a 9 free position electron. The larger free position of electron can partialy doped with another electron so make a good covalent bonding and an average strong field ligand and have a middle spin of electron that support a safety uses as a semiconductor material.

Partially substitution $\mathrm{Fe}^{3+}$ from orthorhombic phase by trivalent $\left(\mathrm{X}^{3+}\right)$ dopant has produced compound of $\mathrm{Fe}_{1-\mathrm{x}} \mathrm{M}_{2} \mathrm{O}_{3}-\delta$ ( $\mathrm{x}=$ dopant concentration, $0-10 \% \mathrm{M}=$ dopant trivalent, and $\delta=$ oxygen void). The substituted orthorhombic structure $\mathrm{Fe}_{2} \mathrm{O}_{3}$ was obtained by atomistic modeling and Bond Valence Sum (BVS) calculations that each of them used GULP (General Utility Lattice 
Programme) and VESTA (Visualization for electronic and structural analysis) software. The stability of $\mathrm{Fe}_{2} \mathrm{O}_{3}$ structure due to the doping is analyzed based on the changing of lattice energy which obtained from the modeling and supported by analysis of structure $\mathrm{Fe}_{2} \mathrm{O}_{3}$ accuracy doped by the use of BVS method.

\section{Methodology}

The instruments used in this research consist of hardware and software. Hardware instrument which is used is a personal computer $(\mathrm{PC})$ of a intel ${ }^{\circledR}$ Core $^{\mathrm{TM}}$ processor with speed 2,53 GHz, RAM 4,00 GB. While the software is the operating System (OS). The object of this research is $\mathrm{Fe}_{2} \mathrm{O}_{3}$ and $\mathrm{Gd}_{2} \mathrm{O}_{3}$ with input of short-range potential parameter that is taken from the previous study from Wei dan Xia This research used theoretical explorative. All materials used in this research are compounds in which the short-range potential calculation result is taken from the previous study. This research used computational chemistry method to explore all the compounds. The General Utilities Grid (Gulp) program has been expanded to include the ability to simulate polymer and surface, as well as adding many other new features, and adding many other new features, and the program's current status is documented. The calculation of mechanical properties as an applied function, computation of dielectric DOI: http://dx.doi.org/10.12962/j25493736.v5i2.7780 data computed at frequencies, reconstruction of the calcite surface and performance of linear scaling algorithms for potential bond orders (Gale and Rohl, 2003). VESTA is a three-dimensional visualization system for crystallographic studies and electronic state calculations. VESTA implementing new features including drawing external crystal morphology; overlay multiple structural models, volumetric data and crystal surfaces; electron and nuclear density calculations of structural parameters, calculation of the Patterson function from structural parameters or volumetric data, integration of electron and nuclear density with Voronoi tessellation, visualization of isosurfaces with multiple levels, determination of the best plane for the selected atom, extended bond search algorithms to allow more sophisticated searches in complex molecules and cage-like structures, undo and redo in the graphical user interface operation, and significant performance improvements in rendering isosurfaces and counting slices (Momma and Izumi, 2011). Modeling using the GULP code is carried out to calculate the lattice energy and cell parameters for pure $\mathrm{ZrO}_{2}$ and doped $\mathrm{ZrO}_{2}$ structures (Kilo, 2019).

\section{GULP Code Input Data Making}

The modeling by using GULP code in this research conducted to calculate lattice energy and parameter of doped cell structure 
$\mathrm{Fe}_{2} \mathrm{O}_{3}$ and $\mathrm{Fe}_{2} \mathrm{O}_{3}$. The modeling carried out requires of cell parameter input data and cell fractional which is reported by Xia and others (1). In addition to the original data of $\mathrm{Fe}_{2} \mathrm{O}_{3}$, $\mathrm{Fe}_{2} \mathrm{O}_{3}$ data doped by trivalent cations based on the increase of dopant concentration from 0 until 9\%. Data is stored in GULP software in a folder according to the name of dopants whose concentration is determined at $1 \%$ until 9\%. After finishing data collected, the next step is processing data by using GULP and BVS software.

\section{Atomistic Modeling Method}

The Atomistic modeling method is based on born model from an Ionic Crystal. The interaction of solid Crystal is described with interatomic potential interaction which consists of long-range interaction (coulomb interaction) and short-range interaction. Short-range interaction is produced by Van Der Waals's repulsion and pull-force. Therefore, the lattice energy (U) is described as:

$$
U=1 / 2 \sum \frac{q_{i} q_{j}}{r_{i j}}+\sum_{i \neq j} S_{i j}
$$

Where $\mathrm{q}$ is an ionic charge, $\mathrm{r}$ is a distance between atoms, and $S_{i j}$ is a short-range interation. The short-range interation in this research used Buckingham potential which is formulated:

$$
S_{i j}=A \operatorname{Exp}\left(\frac{r_{i j}}{\rho}\right)-C / r_{i j^{6}}
$$

Where $S_{i j}$ is valence of a bond, $r_{i j}$ is measurable bond length. A, $\rho$ and $\mathrm{C}$ are empirical parameters which related to ion substance (A), ion size ( $\rho)$, and Van Der Waals interaction (C). Process of lattice minimization in this research was carried out at a constant pressure. In this condition, the dimension of unit cell can change so that the strain inside the cells and ions could be minimized.

\section{Bond Valence Sum (BVS) Method}

BVS is an empirical model to explain the valence or bond strength of ion solids (13). This method is performed with adding up all valence bonds around the atom by using the equation:

$$
S_{i j}=\exp \left(\frac{r_{o}-r_{i j}}{b}\right)
$$

Where, $S_{i j}$ is a valence of a bond, $R_{i j}$ is a measured bond length, and ro is a unit of bond length which is developed for unit of valence bond (a single bond between atom I dan $\mathrm{j}$ ). Meanhwhile B is a constant value. The calculation of effective valence must be in the difference 0,1 for the alleged valence atom (14). For instance, for Fe, where the oxidation number is +3 then the counted bond valence must between 2.9 and 3.1 
The technique of determining BVS uses VESTA, doped $\mathrm{Fe}_{2} \mathrm{O}_{3}$ structure is made in Rhombohedral. The value of bond valence parameter $\mathrm{R}_{0}$ used is 1.928 (15). The length of $\mathrm{Fe}-\mathrm{O}$ bond from all iron cations in different crystal $\mathrm{Fe}_{4} \mathrm{O}_{5}$ structure used the common BVS method (Brese, 1991). Empirical parameter ( $\left.b_{0}\right)$ was about $0.37 \AA$ and BVS value from cations is determined as the sum of each bond valence $\left(\mathrm{V}_{\mathrm{i}}=\mathrm{s}_{\mathrm{ij}} \mathrm{s}_{\mathrm{ij}}\right)$ (Brese, 1991). In this calculation, $\mathrm{b}_{0}=0.37 \AA$ is used and bond valence parameter $R_{i j}$ is determined by surrounding condition for $\mathrm{Fe}^{2+}-\mathrm{O}$ and $\mathrm{Fe}^{3+}-$ O bond, each of them are $\AA 1.734$ dan 1.759 $\AA$ A. Based on literature data from the hematite state equation $\left(\alpha-\mathrm{Fe}_{2} \mathrm{O}_{3}\right)$ which is determined from experiments of single crystal X-ray diffraction until $25 \mathrm{GPa}$ (Schouwink, 2011). The Buckingham Potential

The Buckingham potential consists of repulsion and dispersion interaction. In $\mathrm{Fe}_{2} \mathrm{O}_{3}$ doped by trivalent cations.

\section{Result and Discussion}

The Structure of $\mathrm{Fe}_{2} \mathrm{O}_{3}$

Input data of $\mathrm{Fe}_{2} \mathrm{O}_{3}$ has been made then modeled atomically at constant pressure by using GULP.

The initial stage of modeling which conduct in this research was to optimize and suitability between the generated model through modeling with $\mathrm{Fe}_{2} \mathrm{O}_{3}$ result research data. Input data which is reported is using Tucek (2015). Made input data is better if the structural parts (unit cell parameter) are known in advance, like space group, cell parameter which obtained from X-Ray diffraction data.

Table 1. Crystal System $\mathrm{Fe}_{2} \mathrm{O}_{3}$ from calculation

\begin{tabular}{|c|c|c|c|c|c|}
\hline No & Parameter & $\begin{array}{c}\text { Value } \\
{[\mathrm{A}]}\end{array}$ & No & Parameter & $\begin{array}{c}\text { Value } \\
{[\mathrm{A}]}\end{array}$ \\
\hline 1 & Volume [A] & 850.4 & 23 & $\mathrm{Fe}(6) \mathrm{x}$ & 0.500 \\
\hline 2 & A & 9.683 & 24 & $\mathrm{Fe}(6) \mathrm{y}$ & 0.250 \\
\hline 3 & B & 10.00 & 25 & $\operatorname{Fe}(6) z$ & 0.716 \\
\hline 4 & $\mathrm{C}$ & 8.949 & 26 & $\mathrm{O}(1) \mathrm{x}$ & 0.083 \\
\hline 5 & Alpha & & 27 & $\mathrm{O}(1) \mathrm{y}$ & 0.371 \\
\hline 6 & Beta & 101.10 & 28 & $\mathrm{O}(1) \mathrm{z}$ & 0.147 \\
\hline 7 & Gamma & & 29 & $\mathrm{O}(2) \mathrm{x}$ & 0.417 \\
\hline 8 & $\operatorname{Fe}(1) x$ & 0.000 & 30 & $\mathrm{O}(2) \mathrm{y}$ & 0.629 \\
\hline 9 & $\mathrm{Fe}(1) \mathrm{y}$ & 0.000 & 31 & $\mathrm{O}(2) \mathrm{z}$ & 0.647 \\
\hline 10 & $\mathrm{Fe}(1) \mathrm{z}$ & 0.000 & 32 & $\mathrm{O}(3) \mathrm{x}$ & 0.147 \\
\hline 11 & $\operatorname{Fe}(2) x$ & 0.250 & 33 & $\mathrm{O}(3) \mathrm{y}$ & 0.083 \\
\hline 12 & $\mathrm{Fe}(2)$ y & 0.296 & 34 & $\mathrm{O}(3) \mathrm{z}$ & 0.371 \\
\hline 13 & $\mathrm{Fe}(2) \mathrm{z}$ & 0.000 & 35 & $\mathrm{O}(4) \mathrm{x}$ & 0.353 \\
\hline 14 & $\operatorname{Fe}(3) x$ & 0.750 & 36 & $\mathrm{O}(4) \mathrm{y}$ & 0.917 \\
\hline 15 & $\mathrm{Fe}(3)$ y & 0.225 & 37 & $\mathrm{O}(4) \mathrm{z}$ & 0.871 \\
\hline 16 & $\mathrm{Fe}(3) \mathrm{z}$ & 0.500 & 38 & $O(5) x$ & 0.353 \\
\hline 17 & $\operatorname{Fe}(4) x$ & 0.000 & 39 & $\mathrm{O}(5) \mathrm{y}$ & 0.147 \\
\hline 18 & $\mathrm{Fe}(4) \mathrm{y}$ & 0.500 & 40 & $\mathrm{O}(5) \mathrm{z}$ & 0.083 \\
\hline 19 & $\mathrm{Fe}(4) \mathrm{z}$ & 0.000 & 41 & $O(5) x$ & 0.871 \\
\hline 20 & $\operatorname{Fe}(5) x$ & 0.216 & 42 & O(5)y & 0.353 \\
\hline 21 & $\mathrm{Fe}(5) \mathrm{y}$ & 0.000 & 43 & $\mathrm{O}(5) \mathrm{z}$ & 0.917 \\
\hline 22 & $\mathrm{Fe}(5) \mathrm{z}$ & 0.750 & & & \\
\hline
\end{tabular}


Structure and Oxygen Void Doped $\mathrm{Fe}_{2} \mathrm{O}_{3}$

Dopant concentration of trivalent cations which substituted Fe partially as much as $1 \%-9 \%$. The previous study shown that there were greater activity at doped $\mathrm{Fe}_{2} \mathrm{O}_{3}$ in dopant concentration below $10 \%$. That substitution is balanced with the result of reaction in the form of iron oxide $(\mathrm{FeO})$. The bigger dopant concentration which substitutes $\mathrm{Fe}^{3+}$, the smaller amount of occupancy value from oxygen (filled oxygen), or in other words, can result the smaller oxygen void as we call it a vacancy (V).

There are two procedures to achieve structure stability, the first one is doing cations doping which has greater valence to expand the lattice or the second one is to do cations doping which has the same valence just like what the researchers do in this study. The doping mechanism which has the same valence will reduce or minimized draft of the oxygen void just like the following reaction equation :

$$
\frac{1}{2} \mathrm{M}_{2} \mathrm{O}_{3}+\frac{3}{2} \mathrm{Fe}_{\mathrm{Fe}^{\mathrm{x}}} \rightarrow \mathrm{MFe}^{\bullet}+\frac{1}{2} \mathrm{VF}^{\prime \prime}+\frac{3}{2} \mathrm{FeO}
$$

(Islam, 2005)

The reaction equation above can be stated that one ion $\mathrm{M}^{3+}$ substitutes 3 ions $\mathrm{Fe}^{3+}$ and there's no oxygen void. The formation of electrolyte $\mathrm{FeO}$ which has neutral charged occurred, so that there was no released electron. Dopant which is used was trivalent cations derived from trivalent oxide of rare earth metals $\mathrm{M}^{3+}$. The interaction occurred in this research was an ionic potential.

Buckingham Potential Doped $\mathrm{Fe}_{2} \mathrm{O}_{3}$ by trivalent Cations

The Buckingham potential of dopant ion (trivalent oxide) in $\mathrm{Fe}_{2} \mathrm{O}_{3}$ with a short-range could be seen at table 2 .

Table 2. Buckingham potential doped $\mathrm{Fe}_{2} \mathrm{O}_{3}$ by trivalent cations

\begin{tabular}{cccc}
\hline Short Range & $\mathrm{A}[\mathrm{eV}]$ & $\mathrm{P}[\mathrm{A}]$ & $\mathrm{C}[\mathrm{eV} . \mathrm{A}]$ \\
\hline $\mathrm{Gd}^{3+}-\mathrm{O}_{2}^{-}$ & 1885,75 & 0,3399 & 20,34 \\
\hline
\end{tabular}

Source : (Li, 2012)

Table 3. Charge and ions spring of $\mathrm{Fe}_{2} \mathrm{O}_{3}$ doped by cation $\mathrm{Gd}^{3+}$

\begin{tabular}{ccc}
\hline Shell Model & $\mathrm{k}[\mathrm{eV} \mathrm{A}$ & Shell [e] \\
\hline $\mathrm{Gd}^{3+}$ & 299,96 & 3,973
\end{tabular}

Source: (Malik, 2018)

According to Buckingham Potential $\mathrm{Gd}^{3+}$, it has high polarisability and low repulsion, so it has geometry regularity which facilitates oxygen ion to do the migration. Doping by $\mathrm{Gd}^{3+}$ is believed to reduce synthesis temperatures. The charge and ions spring in $\mathrm{Fe}_{2} \mathrm{O}_{3}$ is doped by cation $\mathrm{Gd}^{3+}$.

\section{Cell Parameter}

The changed that occur at unit cell parameter structure due to the entry of dopant $\mathrm{Gd}^{3+}$. Modeling result for cell parameter (shown in length sides) a, b, and c. From the 
Suprabawati, dkk. Akta Kimia Indonesia 5(2), 2020, 53-61

table, we can see that doping with cations $\mathrm{Gd}^{3+}$ could increase cell parameter. The bigger of the radius, the cell parameters could be raised. To prove the change of cell parameter from crystal lattice, a calculation is made toward the distance between ions within the crystals. Two dopant cations that substituted $\mathrm{Fe}_{2} \mathrm{O}_{3}$ structure took the closest place with oxygen, that is the last oxygen $(\mathrm{Fe}-\mathrm{O}(3))$, with the closest distance of $1.67 \AA$ compared from distance of the first $\mathrm{O}$ that is $1.67 \AA$ and distance with second oxygen $1.82 \AA$ (Peters, 2017).

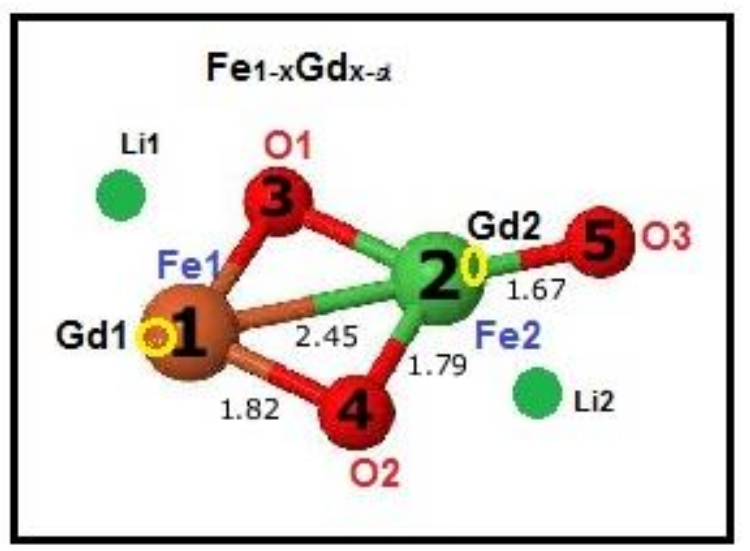

Figure 1. Distance between Gd-O and Gd-Gd of $\mathrm{Fe}_{1-\mathrm{x}} \mathrm{Gd}_{\mathrm{x}}$ Structure (Vesta, 2020).

The more concentration increase and the size of dopant that substituted $\mathrm{Fe}_{2} \mathrm{O}_{3}$, the bigger distance between dopant (Gd- Gd) and dopant $\mathrm{O}$, because of the greater repulsion between dopant and oxygen within the structure. This causes lattice cell parameter getting bigger and the stability structure of doped $\mathrm{Fe}_{2} \mathrm{O}_{3}$ decrease.
Table 4. Cell parameter of $\mathrm{Fe}_{2} \mathrm{O}_{3}$ doped by cation $\mathrm{Gd}^{3+}$ From reference

\begin{tabular}{llccc}
\hline No & \multicolumn{1}{c}{$\begin{array}{c}\text { Dopan } \\
\text { Concentration }\end{array}$} & $\begin{array}{c}\mathrm{a} \\
{[\mathrm{nm}]}\end{array}$ & $\begin{array}{c}\mathrm{b} \\
{[\mathrm{nm}]}\end{array}$ & $\begin{array}{c}\mathrm{C} \\
{[\mathrm{nm}]}\end{array}$ \\
\hline 1 & $0 \%$ & 1,0324 & 0,6007 & 0,4695 \\
2 & $70 \%$ & 1,0471 & 0,6092 & 0,4758 \\
\hline
\end{tabular}

Source: (Pang, 2012)

Table 5. Cell parameter of $\mathrm{Fe}_{2} \mathrm{O}_{3}$ doped by cation $\mathrm{Gd}^{3+}$ From experiment.

\begin{tabular}{c|l|c|c|c}
\hline No & \multicolumn{1}{c}{$\begin{array}{c}\text { Dopan } \\
\text { Concentration }\end{array}$} & \multicolumn{1}{c}{$\begin{array}{c}\mathrm{a} \\
{[\mathrm{nm}]}\end{array}$} & \multicolumn{1}{c}{$\begin{array}{c}\mathrm{b} \\
{[\mathrm{nm}]}\end{array}$} & \multicolumn{1}{c}{$\begin{array}{c}\mathrm{C} \\
{[\mathrm{nm}]}\end{array}$} \\
\hline 1 & $0 \%$ & 1.0324 & 0.6007 & 0.4695 \\
\hline 2 & $10 \%$ & 1.0337 & 0.6015 & 0.4697 \\
\hline 3 & $50 \%$ & 1.0337 & 0.6015 & 0.4694 \\
\hline 4 & $70 \%$ & 1.0471 & 0.6092 & 0.4758 \\
\hline 5 & $90 \%$ & 1.0328 & 0.60057 & 0.46904 \\
\hline
\end{tabular}

Source: (Suprabawati, 2019)

Table 6. Ion radius from several dopant

\begin{tabular}{cc}
\hline Dopant & Ion Radius [A] \\
\hline $\mathrm{La}$ & 1.15 \\
$\mathrm{Nd}$ & 0.995 \\
$\mathrm{Sm}$ & 0.964 \\
$\mathrm{Eu}$ & 0.950 \\
$\mathrm{Gd}$ & 0.938 \\
\hline
\end{tabular}

\section{Lattice Parameter}

The result of $\mathrm{Fe}_{2} \mathrm{O}_{3}$ optimization, it is found that doped $\mathrm{Fe}_{2} \mathrm{O}_{3}$ lattice energy by $\mathrm{Gd}$ at Born Haber cycle is $13.681 \mathrm{~kJ} / \mathrm{mol}$ or equivalent to $14.228 \times 10^{-2} \mathrm{eV}$. The lattice energy $\mathrm{Fe}_{2} \mathrm{O}_{3}$ before doping is $14,774 \mathrm{~kJ} / \mathrm{mol}$ or equivalent to $15.364 \times 10^{-2} \mathrm{eV}$ (Jain, 2013).

The formation of cations and anions that met the octet rules from their atoms did not 
indicate the stability of an ionic compound (Effendy, 2008). It comes from crystal lattice energy which is released when the crystal formed. Based on this fact, the determination of the stability doped $\mathrm{Fe}_{2} \mathrm{O}_{3}$ structure is done by calculating the crystal energy.

\section{Conclusion}

$\mathrm{Fe}_{2} \mathrm{O}_{3}$ with rhombohedral structure which already doped by trivalent cations Gadolinium $\left(\mathrm{Gd}^{3+}\right)$ partially causes the doped $\mathrm{Fe}_{2} \mathrm{O}_{3}$ structure experienced an oxygen void and the decrease of stability. Decrease stability will directly proportional as dopant concentration. The dopant concentration can affect the lattice crystal energy. The Formation of ionic compound with lattice energy produced negative enthalpy changes (exothermic) due to that ionic compound are in a more stable state (strong bond energy). By linking the analysis of cell parameters and lattice energy, it is found that the bigger dopant radius which substituted $\mathrm{Fe}_{2} \mathrm{O}_{3}$, the more increase (positive) lattice energy of doped $\mathrm{Fe}_{2} \mathrm{O}_{3}$. With the inclusion of trivalent dopant that has big radius, caused $\mathrm{Fe}_{2} \mathrm{O}_{3}$ structure becomes less stable because there's a defect/void formed. Moreover, distance between ion within crystals is getting wider, causing bond energy between ion inside weaker and the lattice energy becomes more positive.

\section{References}

[1] Jain. Anubhav and Ong, Shyue Ping and Hautier, Geoffroy and Chen, Wei and Richards, William Davidson and Dacek, Stephen and Cholia, Shreyas and Gunter, Dan and Skinner, David and Ceder, Gerbrand and Persson, Kristin a Commentary: The Materials Project: A materials genome approach to accelerating materials innovation. journal APL Materials 2013

[2] Kristin.,P, Computed materials data using density functional theory calculations. These calculations determine the electronic structure of bulk materials by solving approximations to the Schrodinger equation". Materials data on $\mathrm{Gd}_{2} \mathrm{O}_{3}$ (SG:206). Materials Project United States, 2014

[3] La Kilo, Akram. Umamah Triwahyuni S. Laliyo Lukman,A,R. Studi Kestabilan Zirkonia Terdopng Kation Trivalen melalui pemodelan atomistik. Jurnal Kimia Sains dan Aplikasi 22 (4) (2019) : $129-135$

[4] Li zhi,peng. Mori, Toshiyoki. Zou, jin. Drennan Jon. Optimization of ionic conductivity in solid electrolytes through dopant-dependent defect cluster analysis Phys. Chem.2012

[5] Mouni Roy, Milan Kanti Naskar. Alkali metal ion induced cube shaped 
Suprabawati, dkk. Akta Kimia Indonesia 5(2), 2020, 53-61

mesoporous hematite particles for improved magnetic properties and efficient degradation of water pollutants. Physical Chemistry Chemical Physics 2016, 18 (30) , 20528-20541. https://doi.org/10.1039/C6CP02442D

[6] Nidha, 2017. Logam Dan Material, Fenomena Listrik Dan Elektromagnet, Evolusi Mekanika Kuantum.

[7] Oxtoby, Gillis, Nachtrieb, Suminar. Prinsip-prinsip kimia modern. Jakarta : Erlangga,2003

[8] Peters.L, Rossen L, Sasioglu,E. Nonconventional Screening Of The Coulomb Interaction in $\mathrm{Fe}_{\mathrm{x}} \mathrm{O}_{\mathrm{y}}$ clusters : An Ab-initio study. Physics.atm-clus. 2017

[9] Ramanarayanan T,A., Wayne L. Worrell, Harry L. Tuller Proceedings of the Second International Symposium on Ionic and Mixed Conducting Ceramics. Buku The Electrochemical Society, 1994 $-633$

[10] Wells, A.F. (1984) Structural Inorganic Chemistry 5th edition Oxford Science Publications. ISBN 0-19-855370-6.

[11] Xin Xia, Richard Oldman, Richard Catlow, computational Modeling Study of Bulk and Surface of Yttria-stabilized cubic zirconia, chemistry of materials,21,15 (2009) 3576-3585

[12] Xi Wei, Wei Pan, Laifei Cheng, Bin Li, atomistic calculation of association energy in doped ceria, Solid State Ionics, 180,1 (2009) 13-17 